\title{
A cross-sectional study evaluating the awareness of pharmacovigilance among MBBS interns of a teaching hospital in south India
}

\author{
Mohammed Naseeruddin Nadeem ${ }^{1}$, Ayesha Vaseem ${ }^{1}$, Maliha Maqdoom²
}

${ }^{1}$ Department of Pharmacology, Deccan College of Medical Sciences, Hyderabad,

Telangana, India

${ }^{2}$ Department of Physiology, Ayaan Institute of Medical Sciences, Moinabad, Telangana, India

Received: 23 August 2016 Accepted: 24 September 2016

\section{*Correspondence to:}

Dr. Mohammed Naseeruddin Nadeem,

Email:nad040@gmail.com

Copyright: (C) the author(s), publisher and licensee Medip Academy. This is an openaccess article distributed under the terms of the Creative Commons Attribution NonCommercial License, which permits unrestricted noncommercial use, distribution, and reproduction in any medium, provided the original work is properly cited.

\begin{abstract}
Background: Spontaneous reporting is the backbone of any pharmacovigilance programme. The pharmacovigilance programme of India, started in 2010 has not seen considerable success, owing to underreporting of adverse drug reactions (ADRs). This can be attributed to a lack of awareness of pharmacovigilance among the healthcare professionals. This study was conducted with the aim to evaluate the level of knowledge, awareness, attitude and practice of pharmacovigilance among interns of a teaching hospital.

Methods: An observational, cross-sectional study was done among interns of a teaching hospital. A predesigned Questionnaire was distributed among 150 interns, from which 138 completed questionnaires were considered. The questionnaire consisted of 16 questions dealing with knowledge, awareness, attitude and practice of pharmacovigilance. Data was analysed and presented as percentage of respondents.

Results: $71 \%$ interns correctly identified the definition of pharmacovigilance. However, their awareness was deficient, in particular about the existence of an ADR monitoring centre in their own institution (33\%). The rate of ADR reporting was immensely inadequate (12\%), which is a matter of utmost concern and requires immediate attention. The factors discouraging them from reporting ADRs were insufficient knowledge about the reporting procedure and a lack of time to report.

Conclusions: Interns lacked the required level of awareness, attitude and practice of pharmacovigilance, which needs to be resolved instantly by organizing frequent training sessions. Continued medical education programmes and workshops may be helpful in increasing their awareness and consequently to improve the rate of spontaneous ADR reporting.
\end{abstract}

Keywords: Adverse drug reactions, Interns, Pharmacovigilance, Spontaneous reporting

\section{INTRODUCTION}

WHO defines Pharmacovigilance as "The science and activities which are related to the detection, assessment, understanding and the prevention of adverse effects or any other drug related problems". ${ }^{1}$ An adverse drug reaction (ADR) is defined as "Any response to a drug which is noxious and unintended, and which occurs at doses normally used in man for prophylaxis, diagnosis of disease, or for the modification of physiological function."

ADRs is a formidable cause for morbidity and mortality, amounting to $5-20 \%$ of hospitalized patients. ${ }^{3,4}$ It leads to an economic burden both for the affected individual and also for the community as a whole. ${ }^{5}$ ADR Monitoring and its surveillance could prove to be of help in reducing the morbidity and mortality associated with it. However, only 6-10\% of all the ADRs are reported, thus under reporting remains a major limitation for drug safety surveillance. ${ }^{6,7}$ India has a ADR reporting rate of $1 \%$ which is much less when compared to the global ADR reporting rate of $5 \%{ }^{8}$

To address this problem, the Ministry of Health and Family Welfare has initiated a nationwide program known as 'Pharmacovigilance Programme of India' (PvPI), which went ahead with its functioning in July of 2010. ${ }^{9}$ The function of PvPI is to collect ADR data, analyse it and utilize its results as a means to recommend informed regulatory interventions, along with 
communicating the potential risks related to a drug to the health care personals and also to the common population. PvPI is coordinated by the National Coordination Centre, under Indian Pharmacopoeia commission. As per the pharmacovigilance newsletter, the incidence of ADRs reported increased since 2010 in India indicating the progress of reporting. ${ }^{10}$ However, the PvPI still suffers from underreporting of ADRs by the healthcare professionals which can delay the detection of important ADRs. Uppsala Monitoring centre (UMC), the international ADR monitoring centre located at Sweden, which maintains the international ADR database, receives ADRs from all over the world. However, India's contribution to UMC is negligible, owing to the absence of a vigorously active ADR monitoring system due to a dearth in the reporting culture among health care workers. ${ }^{11}$

The success of PvPI relies heavily on spontaneous (voluntary) reporting of suspected ADRs. With remarkably lower cost involved, it contributes a large volume of information to ADR database. It encourages on-going detection of the risk-benefit ratio of drugs, as well as to an early detection of signals of unusual and unsuspected ADRs previously undetected during the initial evaluation of a drug. ${ }^{12}$ The practice of Spontaneous reporting in India is nonetheless in its early stages and is yet to garner pace. ${ }^{13}$ The successful functioning of any pharmacovigilance programme depend highly on the dynamic involvement of all healthcare professionals and the level of participation and communication between the healthcare professionals and the pharmacovigilance center. Insufficient awareness among healthcare professionals concerning detection, communication and spontaneous monitoring of ADRs contributes to underreporting. In order to improve the voluntary ADR reporting rate, it becomes necessary to improve its awareness among healthcare professionals, thereby increasing the practice of spontaneous reporting.

There exist lacunae in studies addressing the knowledge, attitudes and perception of pharmacovigilance system and ADR reporting among healthcare professionals. It has become necessary to conduct extensive studies to analyse and evaluate the role of healthcare professionals along with the inputs they provide towards the growth of pharmacovigilance programme. Several studies done around the world indicate deficiency in knowledge and awareness about pharmacovigilance among healthcare professionals coupled with an indifferent attitude correlated with high degree of underreporting. ${ }^{14-16}$

The ideal training period in a doctor's carrier is during their undergraduate studies, in particular during their internship, where they experience adequate patient exposure to be able to detect an $\mathrm{ADR}^{17}$ Studies are required to be done to assess the level of knowledge and awareness regarding pharmacovigilance amongst interns and if not found up to an acceptable level, then suitable corrective measures are required to be taken in terms of campaigning or training programs. Such assessment also helps us find the reasons for under reporting of ADRs and to plan necessary interventions amongst interns to improve the ADR reporting rate. ${ }^{18}$

In view of the above, the present study was undertaken to evaluate the knowledge, awareness, attitudes and practices of Pharmacovigilance among interns of a teaching hospital in south India.

\section{METHODS}

The present study has been carried out after obtaining permission from institutional ethics committee. This was a cross sectional, questionnaire based study done among MBBS interns of a teaching hospital attached to a medical college in South India.

\section{Design of the questionnaire}

A predesigned questionnaire was developed to obtain information from interns regarding their knowledge and awareness of Pharmacovigilance, attitudes towards reporting ADRs and about their practice of ADR reporting. The questions were also pertaining to gather information regarding their knowledge about the existence and functioning of ADR monitoring centre in the hospital. Objective of one of the questions was to identify the most discouraging factor preventing them from reporting ADRs and another question with the intention to provide us with suggestions to improve rate of spontaneous ADR reporting rate.

\section{Hospitals visits}

The interns were provided with the questionnaire after explanation of the objectives of the study. After taking consent, the participants were asked to answer the questions and return the Questionnaire. They were provided with enough time to fill the questionnaire. In order to maximize the response rate and minimize response bias, the questionnaire was administered personally to the participants by the facilitator. The questionnaire was explained to each practitioner in order to prevent any possible misunderstanding.

\section{Interns' participation}

150 questionnaires were distributed, among which 138 interns responded by submitting the filled questionnaire. Failure to submit on time and incompletely filled in questionnaires were excluded from the study.

\section{Analysis of data}

Data was analysed and presented as percentage (\%) of respondents. 


\section{RESULTS}

Of the total 16 questions in the questionnaire, 6 questions were based on knowledge of Pharmacovigilance, 4 questions on awareness of pharmacovigilance, 4 questions on attitude and practice of ADR reporting, a question on factors discouraging interns from reporting ADRs and a final question on suggestions to improve spontaneous ADR reporting.

Table 1: Knowledge of pharmacovigilance.

\begin{tabular}{|c|c|c|c|}
\hline \multirow[t]{2}{*}{ No. } & \multirow[t]{2}{*}{ Question } & \multicolumn{2}{|c|}{$\begin{array}{l}\text { Response in \% } \\
\text { (out of 138) }\end{array}$} \\
\hline & & Correct & Wrong \\
\hline 1 & $\begin{array}{l}\text { Definition of } \\
\text { Pharmacovigilance is }\end{array}$ & $\begin{array}{l}71 \% \\
(98)\end{array}$ & $\begin{array}{l}29 \% \\
(40)\end{array}$ \\
\hline 2 & $\begin{array}{l}\text { Are you aware of existence } \\
\text { of a National } \\
\text { Pharmacovigilance } \\
\text { Programme in India (PvPI) }\end{array}$ & $\begin{array}{l}62 \% \\
(86)\end{array}$ & $\begin{array}{l}38 \% \\
(52)\end{array}$ \\
\hline 3 & $\begin{array}{l}\text { The national regulatory } \\
\text { body responsible for } \\
\text { monitoring ADRs }\end{array}$ & $\begin{array}{l}57 \% \\
(79)\end{array}$ & $\begin{array}{l}43 \% \\
(59)\end{array}$ \\
\hline 4 & $\begin{array}{l}\text { The PvPI, initiated by } \\
\text { Ministry of Health and } \\
\text { Family Welfare is run by }\end{array}$ & $\begin{array}{l}60 \% \\
(83)\end{array}$ & $\begin{array}{l}40 \% \\
(55)\end{array}$ \\
\hline 5 & $\begin{array}{l}\text { Uppsala monitoring centre } \\
\text { (the Highest centre for } \\
\text { ADR monitoring) is located } \\
\text { in }\end{array}$ & $\begin{array}{l}57 \% \\
(78)\end{array}$ & $\begin{array}{l}43 \% \\
(60)\end{array}$ \\
\hline 6 & $\begin{array}{l}\text { MCI made it mandatory for } \\
\text { all medical colleges to have } \\
\text { a Pharmacovigilance } \\
\text { committee }\end{array}$ & $\begin{array}{l}62 \% \\
(85)\end{array}$ & $\begin{array}{l}38 \% \\
(53)\end{array}$ \\
\hline
\end{tabular}

Table 2: Awareness of pharmacovigilance.

\begin{tabular}{|c|c|c|c|}
\hline \multirow[t]{2}{*}{ No. } & \multirow[t]{2}{*}{ Question } & \multicolumn{2}{|c|}{$\begin{array}{l}\text { Response in \% } \\
\text { (out of 138) }\end{array}$} \\
\hline & & Correct & Wrong \\
\hline 1 & $\begin{array}{l}\text { Healthcare professionals } \\
\text { responsible for reporting } \\
\text { ADRs are }\end{array}$ & $\begin{array}{l}60 \% \\
(83)\end{array}$ & $\begin{array}{l}40 \% \\
(55)\end{array}$ \\
\hline 2 & $\begin{array}{l}\text { Can a Drug be banned due } \\
\text { to ADRs? If yes, give an } \\
\text { example. }\end{array}$ & $\begin{array}{l}58 \% \\
(80)\end{array}$ & $\begin{array}{l}42 \% \\
(58)\end{array}$ \\
\hline 3 & $\begin{array}{l}\text { Is ADR reporting a } \\
\text { professional obligation on } \\
\text { you }\end{array}$ & $\begin{array}{l}42 \% \\
(58)\end{array}$ & $\begin{array}{l}58 \% \\
(80)\end{array}$ \\
\hline 4 & $\begin{array}{l}\text { Are you aware of existence } \\
\text { of a Pharmacovigilance } \\
\text { Centre in your Institute? }\end{array}$ & $\begin{array}{l}33 \% \\
(46)\end{array}$ & $\begin{array}{l}67 \% \\
(92)\end{array}$ \\
\hline
\end{tabular}

Table 1 comprised of questions pertaining to knowledge of pharmacovigilance. $71 \%$ of respondents were able to identify the correct definition of pharmacovigilance. $62 \%$ were aware of the existence of Pharmacovigilance programme of India, whereas only $57 \%$ respondents had knowledge of the national regulatory body responsible for monitoring ADRs. Indian Pharmacopoeia Commission, Ministry of Health and Family Welfare, is functioning as National Coordination Centre at Ghaziabad, which was correctly answered by $60 \%$ of interns. Only $57 \%$ of interns had knowledge of Uppsala Monitoring centre being located in Sweden. $62 \%$ interns had knowledge that Medical council of India has made it mandatory for every medical college to have their own Pharmacovigilance centre.

Table 3: Attitude and practice of ADR reporting.

\begin{tabular}{|c|c|c|c|}
\hline \multirow[t]{2}{*}{ No. } & \multirow[t]{2}{*}{ Question } & \multicolumn{2}{|c|}{$\begin{array}{l}\text { Response in \% } \\
\text { (out of 138) }\end{array}$} \\
\hline & & Correct & Wrong \\
\hline 1 & $\begin{array}{l}\text { Ever experienced an ADR } \\
\text { during your clinical } \\
\text { postings }\end{array}$ & $\begin{array}{l}48 \% \\
(66)\end{array}$ & $\begin{array}{l}52 \% \\
(72)\end{array}$ \\
\hline 2 & $\begin{array}{l}\text { Ever reported any ADR to a } \\
\text { Pharmacovigilance centre }\end{array}$ & $\begin{array}{l}12 \% \\
(16)\end{array}$ & $\begin{array}{l}88 \% \\
(122)\end{array}$ \\
\hline 3 & $\begin{array}{l}\text { Ever seen an ADR } \\
\text { reporting form }\end{array}$ & $\begin{array}{l}20 \% \\
(28)\end{array}$ & $\begin{array}{l}80 \% \\
(110) \\
\end{array}$ \\
\hline 4 & $\begin{array}{l}\text { Ever seen Red ADR boxes } \\
\text { meant for inserting filled } \\
\text { ADR forms in your hospital }\end{array}$ & $\begin{array}{l}53 \% \\
(73)\end{array}$ & $\begin{array}{l}47 \% \\
(65)\end{array}$ \\
\hline
\end{tabular}

Table 2 revealed the awareness of interns about pharmacovigilance. $60 \%$ interns were aware that the healthcare professionals responsible for reporting ADRs included doctors, nurses and pharmacists. 58\% interns were aware that a drug can be banned due to ADRs, and when asked to give an example, most of them gave the example of thalidomide. $42 \%$ interns responded correctly that ADR reporting is not a professional obligation on them. Only $33 \%$ interns were aware that their medical college has a functional pharmacovigilance centre.

Table 4: Factors which discourages you the most from reporting an $A D R$.

\begin{tabular}{|lll|}
\hline & \multicolumn{1}{|c|}{$\begin{array}{c}\text { Response in \% } \\
\text { (out of 138) }\end{array}$} \\
\hline & $\begin{array}{l}\text { No remuneration } \\
\text { Which factor } \\
\begin{array}{l}\text { Lack of time to } \\
\text { report ADR }\end{array}\end{array}$ & $32 \%(45)$ \\
\cline { 2 - 3 } $\begin{array}{l}\text { discourages } \\
\text { from the most } \\
\text { reporting an } \\
\text { ADR }\end{array}$ & $\begin{array}{l}\text { A single unreported } \\
\text { case may not affect } \\
\text { ADR database }\end{array}$ & $9 \%(12)$ \\
\cline { 2 - 3 } & $\begin{array}{l}\text { Difficult to decide } \\
\text { whether ADR has } \\
\text { occurred or not }\end{array}$ & $11 \%(15)$ \\
\cline { 2 - 3 } & $\begin{array}{l}\text { No knowledge of } \\
\text { reporting procedure }\end{array}$ & $42 \%(58)$ \\
\hline
\end{tabular}

Table 3 involved questions related to attitudes and practices of ADR reporting. Only $48 \%$ interns encountered an ADR in their clinical postings, among which only 16 interns (12\%) reported the ADRs to ADR 
centre. $80 \%$ interns had never seen an ADR reporting form. 53\% interns were aware of the presence of ADR boxes in their hospital, but a majority among them did not know its purpose.

Table 4 deals with factors discouraging interns from reporting ADRs. $6 \%$ interns felt that the practice of ADR reporting lacked remuneration benefit. 33\% interns felt they lacked time to report ADRs. 9\% interns were of the opinion that reporting a single case may not benefit the ADR database. $11 \%$ interns responded that they lacked confidence to decide whether ADR has occurred or not and $42 \%$ interns lacked the knowledge of ADR reporting procedure.

Table 5: Suggestion to improve rate of spontaneous ADR reporting.

\begin{tabular}{|lllll|}
\hline & Response in percentage (out of 138) & & Appreciating reporter \\
& $\begin{array}{l}\text { Conducting } \\
\text { CMEs and } \\
\text { workshops }\end{array}$ & $\begin{array}{l}\text { Incorporating } \\
\text { knowledge of } \\
\text { pharmacovigilance in } \\
\text { MBBS curriculum }\end{array}$ & $\begin{array}{l}\text { Giving } \\
\text { acknowledgement } \\
\text { receipts to the } \\
\text { reporter }\end{array}$ & $\begin{array}{l}\text { Aprough print bulletin/ } \\
\text { throcial network group of } \\
\text { socilege } \\
\text { college }\end{array}$ \\
\hline $\begin{array}{l}\text { Your suggestion to improve } \\
\text { rate of spontaneous ADR } \\
\text { reporting }\end{array}$ & $60 \%(83)$ & $31 \%(42)$ & $05 \%(07)$ & $04 \%(06)$ \\
\hline
\end{tabular}

Table 5 provides us with suggestions by interns which are likely to improve ADR reporting rate. Majority of interns (60\%) suggested that more CMEs and workshops related to pharmacovigilance need to be conducted in the institute. $31 \%$ opted that understanding of pharmacovigilance be incorporated in the MBBS curriculum itself. Very few interns $(05 \%)$ were of the opinion that acknowledgement receipts be given to the reporter. And an equally low number of interns (04\%) opted for appreciating the reporter through college print bulletin or by other means.

\section{DISCUSSION}

Our study revealed that the interns of this teaching hospital had inadequate awareness of pharmacovigilance. Only $60 \%$ of interns in our study were aware of the regulatory body responsible for monitoring ADRs which was low when compared to $84 \%$ as reported by Radhakrishnan, et al. and $79 \%$ as reported by Deepak P, et al. ${ }^{19,20}$

Regarding the level of awareness of pharmacovigilance, the one aspect where the interns lacked exceedingly was that of the existence of a pharmacovigilance centre in their own institute. Our results show that the awareness among interns about the existence of an ADR monitoring centre in their hospital is $33 \%$ which is low when compared with the study done by Madhan Ramesh and Gurumurthy Parthasarathi which was $89 \%{ }^{21}$

The interns seemed to lack an encouraging attitude and practice of ADR reporting. In our study, only $12 \%$ subjects reported ADR to the pharmacovigilance centre which is comparable to $18.5 \%$ subjects in a study done by Kharkar M and Bowalekar S and $28.5 \%$ in a study done by Qing $\mathrm{L}$ et al. ${ }^{22,23}$ A low rate of ADR reporting by interns $(12 \%)$ undoubtedly needs to be resolved.
In our study, $42 \%$ of the interns had the viewpoint that $\mathrm{ADR}$ reporting is a professional obligation, which is comparable to a similar study done by Deepak, et al. in which $47 \%$ of medical students had the same perspective. Also this finding was comparable to those from other similar studies done by Qing L et al., and Belton KJ et al., but was not comparable to the findings by Bateman et al. ${ }^{20,23-25}$

A large number of interns (42\%) did not know the actual procedure of reporting ADRs. When enquired further, they revealed that they found difficulty in filling the form, as to where the ADRs be reported and also to whom they should be reported.

Most of the respondents wanted that the reporter's identity should not be disclosed. To improve the spontaneity in the reporting rates, the interns suggested organizing training programmes and an unsophisticated reporting system with a prompt personal feedback regarding their specific reports. A similar study done by Tabali $\mathrm{M}$ et al., showed that an educational intervention could increase the physicians' awareness on ADRs and how it will help them to implement the knowledge that they gained from the training sessions into their clinical practice. The training programmes which need to be conducted may include continuing medical education, seminars and workshops organized on a regular basis. ${ }^{26}$

\section{CONCLUSION}

The present study suggests that the lack of awareness, attitudes and practice of pharmacovigilance among interns is noteworthy and is a matter of concern requiring immediate attention. In order to execute the objectives laid down by PvPI, the foremost of which is to increase the number of spontaneous reporting of ADRs, it remains the responsibility of interns to voluntarily report any 
ADR they come across. To accomplish this goal, more number of training sessions comprising continuing medical education programmes and workshops on pharmacovigilance are required to be conducted. Interns should be trained about the complete process of reporting an ADR, starting from filling an ADR form to submitting it to an ADR centre. Pharmacovigilance should be taught as a separate subject to undergraduate MBBS students and be included in their curriculum with a greater emphasis on the importance of ADR reporting and its outcome. In order to generalize our findings, there is a compelling need for similar studies to be conducted in other south Indian teaching hospitals as well.

Funding: No funding sources

Conflict of interest: None declared

Ethical approval: The study was approved by the Institutional Ethics Committee

\section{REFERENCES}

1. Pharmacovigilance. World Health Organization. 2016 Available from: http://www.who.int/medicines/areas/quality_safety/sa fety_efficacy/pharmvigi/en/.

2. Adverse Drug Reactions Database [Internet]. Adrdatabase.com. 2016. Available from: http://www.adrdatabase.com/What\%20are\%20ADRs.html\#Definitio n.

3. Lazarou J, Pomeranz B, Corey P. Incidence of Adverse Drug Reactions in Hospitalized Patients: a meta - analysis of prospective studies. JAMA. 1998;279(15):1200.

4. Pirmohamed M. Adverse drug reactions as cause of admission to hospital: prospective analysis of 18,820 patients. BMJ. 2004;329(7456):15-9.

5. Ayani I, Aguirre C, Gutiérrez G, Madariaga A, Rodríguez-Sasiaín J, Martínez-Bengoechea M. A cost-analysis of suspected adverse drug reactions in a hospital emergency ward. Pharmacoepidemiology and Drug Safety. 1999;8(7):529-34.

6. Lopez-Gonzalez E, Herdeiro M, Figueiras A. Determinants of Under-Reporting of Adverse Drug Reactions. Drug Safety. 2009;32(1):19-31.

7. Feely J, Moriarty S, O'Connor P. Stimulating reporting of adverse drug reactions by using a fee. BMJ. 1990;300(6716):22-3.

8. Prakash S. Pharmacovigilance in India. Indian $\mathbf{J}$ Pharmacol. 2007;39:123-3.

9. Gupta YK. Ensuring Patient Safety - Launching the New Pharmacovigilance Programme of India. Pharma Times. 2010;42:21-6.

10. ISPOR India. Pharmacovigilance Programme of India (PvPI). ISPOR India; 2013. Available from: http://www.isporindia.com/wp-content/ uploads/2013/04/Dr.-V.-Kalaiselvan.pdf

11. Inman $\mathrm{WH}$. The attitudes to the adverse drug reaction reporting. Br J Clin Pharmacol. 1996;41:433-5.
12. Edwards I, Olsson S. WHO: global monitoring. In: Pharmacovigilance, Mann RD, Andrew E, editors. Chichester: John Wiley and Sons; 2002:169-182.

13. Indian Pharmacopoeia Comission. 2016. Available from: http://www.ipc.gov.in/PvPI/WHO\% 20news.pdf.

14. Williams D, Feely J. Underreporting of adverse drug reactions: attitudes of Irish doctors. Irish Journal of Medical Science. 1999;168:257-61.

15. Perlik F, Slanar O, Smid M, Petracek J. Attitude of Czech physicians to adverse drug reaction reporting. European Journal of Clinical Pharmacology. 2002;58(5):367-9.

16. Figueiras A, Tato F, Fontainas J, Gestal-Otero J. Influence of Physicians' Attitudes on Reporting Adverse Drug Events. Medical Care. 1999;37(8):80914.

17. Gupta P, Udupa A. Adverse drug reaction reporting and Pharmacovigilance: Knowledge, attitudes and perceptions amongst resident doctors. J Pharma Sci Res. 2011;3:1064-9.

18. Kamtane R, Jayawardhani V. Knowledge, attitude and perception of physicians towards adverse drug reaction (ADR) reporting: A pharmacoepidemiological study. Asian J Pharm Clin Res. 2012;5(3):210-4.

19. Radhakrishnan R, Sudha V, Danturulu MV. An educational intervention to assess knowledge attitude practice of Pharmacovigilance among health care professionals in an Indian tertiary care teaching hospital. International Journal of PharmTech Research. 2011;3(2):678-92.

20. Deepak P, Jayashree V Nagaral. Awareness of Pharmacovigilance among medical students. International Journal of Recent Trends in Science and Technology. 2014; 13(2): 262-65.

21. Ramesh M, Parthasarathi G. Adverse drug reaction reporting: the attitudes and the perceptions of the medical practitioners. Asian Journal of Pharmaceutical and Clinical Research. 2009;2(2):104.

22. Kharkar M, Bowalekar S. Knowledge, attitude and perception/practices (KAP) of medical practitioners in India towards adverse drug reaction (ADR) reporting. Perspect Clin Res. 2012;3(3):90.

23. Qing L, Su-min Z, Hua-ting C, Shi-ping F, Xin Y, Dong $\mathrm{L}$, et al. Awareness and attitudes of healthcare professional in Wuhan, China to the reporting of adverse drug reactions. Chinese Medical Journal. 2004;117(6):856-61.

24. Belton K, Lewis S, Payne S, Rawlins M, Wood S. Attitudinal survey of adverse drug reaction reporting by medical practitioners in the United Kingdom. British Journal of Clinical Pharmacology. 1995;39(3):223-6.

25. Bateman DN, Sanders GL, Rawlins MD. Attitudes to adverse drug reaction reporting in the Northern Region. British Journal of Clinical Pharmacology. 1992;34(5):421-6. 
26. Tabali M, Jeschke E, Bockelbrink A, Witt CM, Willich SN, Ostermann T. Educational intervention to improve the physician reporting of the adverse drug reactions (ADRs) in a primary care setting in the complementary and alternative medicine programs. BMC Public Health. 2009;9(1):274.

Cite this article as: Nadeem MN, Vaseem A, Maqdoom M. A cross-sectional study evaluating the awareness of pharmacovigilance among MBBS interns of a teaching hospital in south India. Int $\mathbf{J}$ Basic Clin Pharmacol 2016;5:2468-75. 
Pharmacovigilance questionnaire

Profession: Age: Sex:

Please tick on the most appropriate option:

1. Pharmacovigilance is:

a) improving safety of the drug

b) detecting Adverse Drug Reactions (ADRs) after drug is marketed

c) monitoring ADR's in a Hospital

d) detection, assessment, understanding and prevention of ADRs

2. Are you aware of existence of a National Pharmacovigilance Programme in India (PvPI)?

a) $\quad$ Yes

b) No

3. The national regulatory body responsible for monitoring ADRs?

a) Indian Council of Medical Research (ICMR)

b) Indian Clinical Research Institute (ICRI)

c) Medical Council of India (MCI)

d) Central Drugs Standard Control Organization (CDSCO)

4. The PvPI, initiated by Ministry of Health and Family Welfare is run by

a) Medical council of India, New Delhi

b) National coordination centre, Ghaziabad

c) World health organization

d) AIIMS, New Delhi

5. Uppsala monitoring centre (the highest center for ADR monitoring) is located in

a) Unites States of America

b) United Kingdom

c) France

d) Sweden

6. ADR reporting is a professional obligation on you

a) Agree

b) Disagree

7. Healthcare professionals responsible for reporting ADRs

a) Doctors

b) Nurses

c) Pharmacist

d) All of the above

8. Can a Drug be banned due to ADRs?

a) If Yes, give an Example:

b) No

c) Don't know 
9. Ever experienced an ADR during your clinical postings?
a) $\quad$ Yes
b) No

10. Ever reported any ADR to a Pharmacovigilance centre?
a) Yes
b) $\quad$ No
c) No, Don't know where to submit the ADR reporting form
d) No, Don't know how to fill up the ADR reporting form

11. Ever seen an ADR reporting form?
a) Yes
b) $\quad \mathrm{No}$

12. Is there a Pharmacovigilance centre in your Institute?
a) Yes
b) $\quad \mathrm{No}$
c) Not yet formed
d) Don't know

13. MCI has made it mandatory for all medical colleges to have a functional Pharmacovigilance committee
a) Yes
b) No
c) Don’t know

14. Red ADR boxes meant for inserting filled ADR forms are installed at multiple places in your hospital
a) Yes
b) No
c) Don't know
d) Seen, but not aware of its purpose

15. Which factor discourages you from reporting ADRs?
a) No remuneration
b) Lack of time to report ADR
c) A single unreported case may not affect ADR database
d) Difficult to decide whether ADR has occurred or not
e) No knowledge of reporting procedure
16. Suggestions to increase ADR reporting and its awareness.
a) conducting CMEs and workshops
b) incorporating in MBBS syllabus
c) giving acknowledgement receipts to the reporter
d) appreciating reporter through print bulletin/ social network group of college

Any other suggestions: 